Note

\title{
IDENTIFICATION OF GENETICALLY MODIFIED SOYBEAN SEEDS RESISTANT TO GLYPHOSATE
}

\author{
Maria Ângela André Tillmann ${ }^{1 *}$; Shirlie West ${ }^{2}$ \\ ${ }^{1}$ UFPel/FAEM-Depto. de Fitotecnia - 96001-970 - Pelotas, RS - Brasil. \\ ${ }^{2}$ University of Florida, Agronomy Seed Laboratory - P.O.BOX 110770 - Gainesville, FL 32611-0770 - USA. \\ *Corresponding author 〈matilman@ufpel.tche.br>
}

ABSTRACT: Advances in genetic engineering permit the modification of plants to be tolerant to certain herbicides that are usually not selective. For practical and commercial purposes, it is important to be able to detect the presence or absence of these traits in genotypes. The objective of this research was to develop a procedure for identifying genetically modified soybean (Glycine max L. Merr.) with resistance to the herbicide glyphosate. Two studies were conducted based on germination test. In the first study, soybean seeds were pre-imbibed in paper towel with the herbicide solutions, then transferred to moist paper towel for the germination test. In the second study, seeds were placed directly in herbicide solutions in plastic cups and tested for germination using the paper towel method. Eight soybean genotypes were compared: four Roundup Ready, that contained the gene resistant to the herbicide (G99-G725, Prichard RR, G99G6682, and H7242 RR) and four non-transgenic parental cultivars (Boggs, Haskell, Benning, and Prichard). In the first study, the seeds were imbibed for 16 hours at $25^{\circ} \mathrm{C}$ in herbicide concentrations between 0.0 and $1.5 \%$ of the glyphosate active ingredient. In the second, seeds were subjected to concentrations between 0.0 and $0.48 \%$, for one hour, at $30^{\circ} \mathrm{C}$. The evaluation parameters were: germination, hypocotyl length, root length and total length of the seedlings. Both methods are efficient in identifying glyphosate-resistant soybean genotypes. It is possible to identify the genetically modified soybean genotypes after three days, by imbibing the seed in $0.12 \%$ herbicide solution, and after six days if the substrate is pre-imbibed in a $0.6 \%$ herbicide solution. The resistance trait was identified in all cultivars, independent of the initial physiological quality of the seed.

Key words: transgenic, germination, detection, glyphosate

\section{IDENTIFICAÇÃO DE SEMENTES DE SOJA GENETICAMENTE MODIFICADA RESISTENTE AO GLIFOSATO}

RESUMO: Avanços na engenharia genética têm resultado na obtenção de plantas tolerantes a certos herbicidas que usualmente não são seletivos. Para fins práticos e comerciais é importante ser capaz de detectar a presença ou ausência dessas características nos genótipos. O objetivo desta pesquisa foi desenvolver um procedimento para identificação de soja (Glycine max L. Merr.) geneticamente modificada com resistência ao herbicida glifosato. Dois estudos foram conduzidos baseados no teste de germinação. No primeiro estudo, sementes de soja foram pré-embebidas em papel toalha com solução do herbicida e após transferidas para papel toalha umedecido para o teste de germinação. No segundo estudo, as sementes foram colocadas diretamente nas soluções do herbicida em copos plásticos e avaliada a germinação pelo método do papel toalha. Oito genótipos de soja foram comparados: quatro Roundup Ready, que contém o gen de resistência ao herbicida (G99-G725, Prichard RR, G99-G6682 e H7242 RR) e quatro cultivares parentais não transgênicas (Boggs, Haskell, Benning e Prichard). No primeiro estudo, as sementes foram embebidas por 16 horas a $25^{\circ} \mathrm{C}$ nas concentrações do herbicida entre 0,0 e $1,5 \%$ do ingrediente ativo glifosato. No segundo, sementes foram submetidas a concentrações entre 0,0 e $0,48 \%$, por uma hora, a $30^{\circ} \mathrm{C}$. Os parâmetros de avaliação foram: germinação, comprimento do hipocótilo, comprimento da raiz e comprimento total das plântulas. Ambos os métodos são eficientes na identificação de genótipos de soja que são resistentes ao glifosato. É possível identificar genótipos de soja geneticamente modificada após três dias, pela embebição das sementes em $0,12 \%$ da solução do herbicida e após 6 dias se o substrato for pré embebido em $0,6 \%$ da solução do herbicida. As características de resistência foram identificadas em todas as cultivares, independente da qualidade fisiológica inicial das sementes.

Palavras-chave: transgênica, germinação, detecção, glifosato

Sci. Agric. (Piracicaba, Braz.), v.61, n.3, p.336-341, May/June 2004 


\section{INTRODUCTION}

Transgenic plants, usually called geneticallymodified organisms (GMOs), represent a promising technology that could give vital contribution to the global security of food and fiber. The total area of genetically modified crops has increased more than 35 times, from 1.7 million hectares in 1996 to 58.7 million hectares in 2002 (James, 2002). This high level of adoption reflects the increasing acceptance of genetically modified cultivars among the farmers using this technology in developed and developing countries.

Agrochemical research, especially with glyphosate, has been at the forefront of these biotechnological advances, and some success has been achieved in the engineering of herbicide resistance in transgenic crop plants. Glyphosate (N-phosphonomethyl-glycine) is the active ingredient in the nonselective herbicide Roundup (Cobb, 1992). This herbicide is highly effective against the majority of weeds.

Sixty-two percent of the global transgenic crop area was occupied by soybean modified for tolerance to herbicide in 2002 (James, 2002). The Roundup Ready soybean is the predominant biotechnology product in the United States, occupying 55\% of the total production area of soybean in 2000 (Seed World, 2001). As of 1999, there were over 1000 glyphosate-resistant soybean varieties available from more than 200 seed companies (Lawton, 1999). This has resulted in a dramatic change in weed management tactics in the US and a marked increase in glyphosate use.

The inability of growers and grain companies to segregate GMOs from non-GMOs jeopardizes the export of traditional crops to customers who desire non-GMOs (Olson, 2000). Consumer organizations in Europe, Japan and North America all maintain that $0.1 \%$ GMO material should be the maximum allowed in a product labeled non-GMO (Seed World, 1999).

Because a large portion of North American corn, soybean, cotton and canola production is now represented by genetically modified cultivars, the agriculture industry suddenly faces the need to determine the presence or absence of these traits in seeds, and in subsequently produced grain. In response, seed technologists have been scrambling to develop GMO testing methods. Generally, the tests are based on several techniques, such as the Enzyme Linked Immunosorbant Assay test (ELISA), to detect specific proteins contained in the GMO seeds and Polymerase Chain Reaction (PCR) techniques that present qualitative results by the detection of the presence of DNA-specific sequences. Both procedures are not easily adapted to rapid, routine seed testing laboratories and more simple techniques are preferred.

There is a need to develop tests for identifying GMO seed that are practical, efficient, low cost and eas- ily executed by seed testing laboratories. One alternative could be the use of germination tests, that could be standardized and highly reproducible among the laboratories. The goal of this study was to develop a methodology in routine analyses to detect genetically modified, glyphosate-tolerant soybean cultivars.

\section{MATERIAL AND METHODS}

Two studies were done based on germination tests.

\section{Study 1- Pre-imbibing the seed in a substrate con- taining herbicide solutions}

Eight soybean genotypes were compared: four that contained the gene tolerant to the herbicide (G99G725, Prichard RR, G99-G6682 and H7242 RR) and four non-transgenic parental cultivars (Boggs, Haskell, Benning and Prichard) supplied by the Georgia Department of Agriculture. Seeds were submitted to germination test according to the Rules for Testing Seeds of the Association of Official Seed Analysts (1995), except for the quantity of seeds. Two hundred seeds were divided into four equal replications. The seeds were placed on paper towels pre-imbibed in solutions containing either $0.0,0.6,0.82,1.2$ or $1.5 \%$ of the active ingredient of the herbicide glyphosate (Nphosphonomethyl glycine, $600 \mathrm{~g} \mathrm{~L}^{-1}$ formulated product), for 16 hours in a chamber maintained at $25^{\circ} \mathrm{C}$. Seeds were then transferred to moist paper towels for the germination test. The germination substrate was moistened to a weight equivalent to 2.75 times the weight of the dry paper.

The rolls were placed in plastic boxes to keep them moist and to avoid contact between rolls with different concentrations of the herbicide. The germinator was maintained at $25^{\circ} \mathrm{C}$ and the evaluation was made after five days. The evaluation parameters were: germination, root length and total length of normal seedlings of the genetically-modified organisms (GMOs), germination and total length of seedling of the abnormal, not genetically modified (non-GMO).

\section{Study 2- Imbibing the seed in herbicide solutions}

The same eight soybean cultivars were used. Seeds were submersed in solutions containing the herbicide in the following concentrations: $0.0,0.12,0.24,0.36$ and $0.48 \%$ of active ingredient glyphosate, for one hour, at $30^{\circ} \mathrm{C}$. The immersion of seeds in warm water $\left(30^{\circ} \mathrm{C}\right)$ was used as a vigor test: germination of the less vigorous lots of seed would be decreased. After imbibition, seeds were submitted to the germination test at $30^{\circ} \mathrm{C}$. Evaluations were made after three and five days. On the third day, vigor, hypocotyl length, roots and the total length of the seedlings were measured. On the fifth day the vigor was evaluated, as well as the total length of the abnormal non-GMO seedlings. 


\section{RESULTS AND DISCUSSION}

\section{Study 1- Pre-imbibing the seed in a substrate con- taining herbicide solutions}

For all soybean cultivars with the exception of seed of the cultivar G99G725 which germinated only $72 \%$, germination was high $(>88 \%)$ when the herbicide concentration was zero (Figure 1). The germination process was inhibited even in the lowest concentration of the herbicide $(0.6 \%)$ for the four, non-GMO soybean cultivars. Lilge (2001) observed that rice cultivars also had an equal response to the herbicide ammonium gluphosinate. However, Dode et al. (1999) observed a cultivar difference in response to ammonium gluphosinate. The $1 \mathrm{mg} \mathrm{L}^{-1}$ concentration caused serious effects to rice cultivars BRS-Taim and BRS-Chui, whereas BRS-Firmeza was tolerant to $5 \mathrm{~mL} \mathrm{~L}^{-1}$ of the same herbicide.

Seeds began germination when exposed to different herbicide concentrations, although the herbicide action prevented normal seedling development of all non-

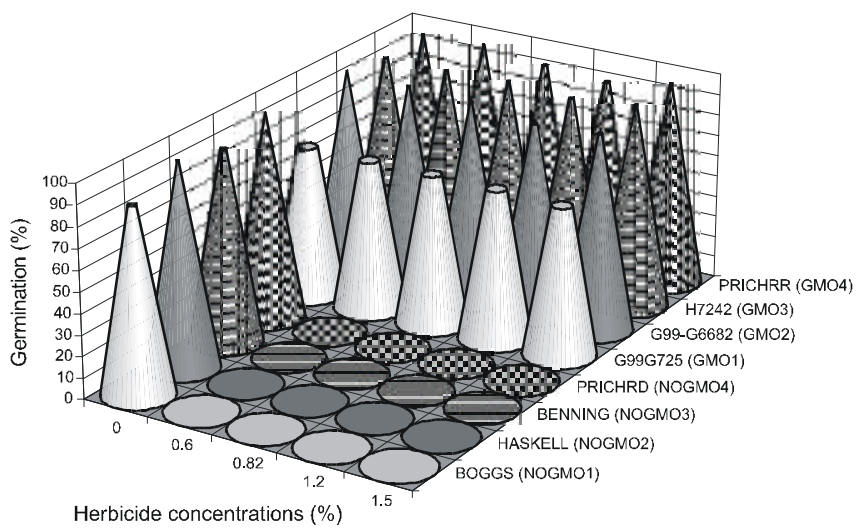

Figure 1 - Germination percentage of seeds of different soybean cultivars, after pre-imbibing the seeds for $16 \mathrm{~h}$ in a substrate containing different herbicide concentrations.

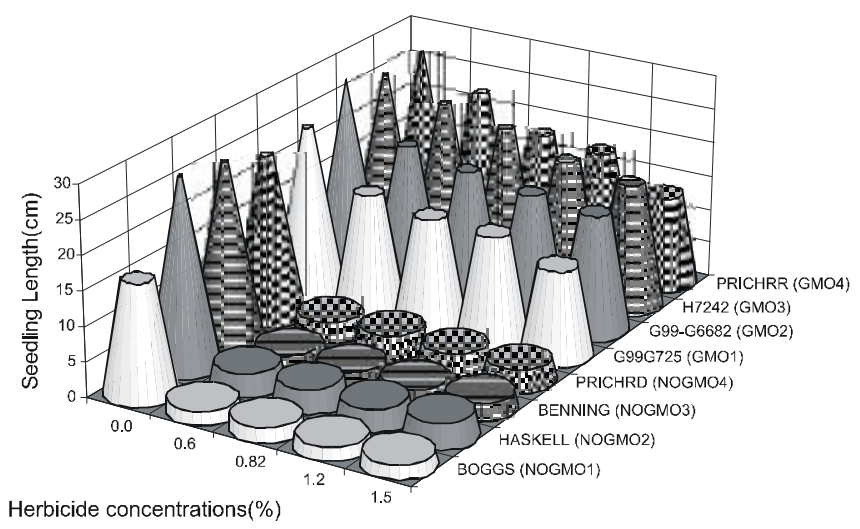

Figure 2 - Total length of normal GMO seedlings and abnormal non-GMO seedlings after pre-imbibing the seed for $16 \mathrm{~h}$ in a substrate containing different herbicide concentrations.
GMO cultivars (Figure 2). Therefore, the seedlings of these cultivars were classified as abnormal. Root growth and secondary root development were inhibited. Total length of the non-GMO abnormal seedlings was drastically reduced regardless the herbicide concentration. Even at the lowest herbicide concentration $(0.6 \%)$ the reduction was $87 \%$ or higher in comparison to the control. Goggi \& Stahr (1997) obtained similar results when testing soybean seed pre-imbibed in Glyphosate solution for 18 hours, at ambient temperature, and later germinated on crepe cellulose paper, covered with moist sand at $25^{\circ} \mathrm{C}, 12$ hours of light. After seven days, root growth ceased in most Glyphosate-susceptible seedlings, and their roots were yellow to brown and stunted, with little or no secondary root growth.

Seed germination of the genetically modified genotypes was not reduced even at the highest concentrations. Glyphosate specifically binds to, and blocks the activity of 5-enolpyruvylshikimate-3-phosphate synthetase (EPSPS) (Steinrucken \& Amrhein, 1980), an enzyme of the aromatic amino acid biosynthetic pathway (Haslam, 1993). EPSPS catalyses the reaction of shikimate-3-phosphate (S3P) and phosphoenolpyruvate (PEP) to form 5-enolpyruvylshkimate-3-phosphate (EPSP) and phosphate. Glyphosate inhibition of EPSPS thus prevents plants from synthesizing aromatic amino acids essential for the synthesis of proteins and some secondary metabolites. In plants, EPSPS is localized in the chloroplasts or plastids (Della-Cioppa et al., 1986). Upon glyphosate treatment, the glyphosate-tolerant soybean plants remained unaffected, because the continued action of the introduced glyphosate-tolerant EPSPS enzyme meets the plants need for aromatic amino acids. This is, in contrast to the death or severe growth reduction, observed upon glyphosate treatment of conventional susceptible soybean (Padgette et al., 1995).

Decrease in total root length of the normal GMO seedlings occurred as the herbicide concentration increased (Figures 2 and 3). Lilge (2001) observed similar results with GMO rice; a decrease was detected in the development of the seedling structures after exposure to the herbicide ammonium gluphosinate. According to Magalhaes et al. (2000), the growth of seedlings of GMO rice was not reduced after exposure of the seedling to a concentration of $0.1 \%$ of the herbicide ammonium gluphosinate. Higher concentrations caused strong necroses in the seedling roots.

According to the seedling length (Figure 2) and root length (Figure 3), H7242 was the most resistant GMO cultivar to all concentrations of the herbicide. The non-GMO cultivar Boggs was less vigorous as determined by the total length of seedlings in the water control (Figure 2). Independent from the herbicide concentration, it was easy to distinguish GMO from the nonGMO cultivars. The GMO cultivars maintained a high 
percentage of germination after exposure to the herbicide. Although there was a reduction of the roots and total plant length, the GMO cultivars were easily told apart from the abnormal, less developed seedlings of non-GMO cultivars, by their stunted primary roots and lack of secondary roots. The $0.6 \%$ herbicide concentration was the best because it caused less reduction in roots and total plant length of genetically modified seedlings.

It is possible to precisely identify GMO soybean seedlings after six days of growth using herbicide preimbibition method. Non-GMO seedlings had severe phytotoxic symptoms and limited growth (Figure 4). The procedure does not affect germination percentage of the GMO cultivars in comparison to non-GMO. In general, the herbicide pre-imbibition method is simple, efficient and inexpensive, and is a good alternative to the other two conventional methods that require sophisticated equipment and qualified technicians.

\section{Study 2 . Imbibing the seed in herbicide solutions.}

In this study, seed were submitted to stress by immersing them in water for 1 hour at $30^{\circ} \mathrm{C}$, before the germination test. At $0.0 \%$ herbicide concentration, seeds from distinct cultivars had different seed vigor (Figure 5). Seed of cultivars G99-G6682, Haskell, and Prichard RR had high physiological quality $(92 \%, 84 \%$ and $81 \%$ germination, respectively) than seed of cultivars Boggs and G99-G725 (48\% and 63\%, respectively).

The non-GMO cultivars were sensitive to the herbicide in all concentrations, as determined by the number of abnormal and poorly developed seedlings (Figures 5 and 6). Similar symptoms were observed in study 1 . In the biotest for the detection of transgenic, glyphosate-resistant lettuce (Lactuca sativa L.), root differentiation and growth in non-transgenic seedlings was inhibited (Nascimento et al., 2001).

Sixty eight percent reduction in the total seedling length (Figure 6) was observed in the lowest concentration $(0.12 \%)$ for all non-GMO cultivars in comparison to the control. In higher concentrations, there was more damage. Earlier application of glyphosate, inhibits a spe-

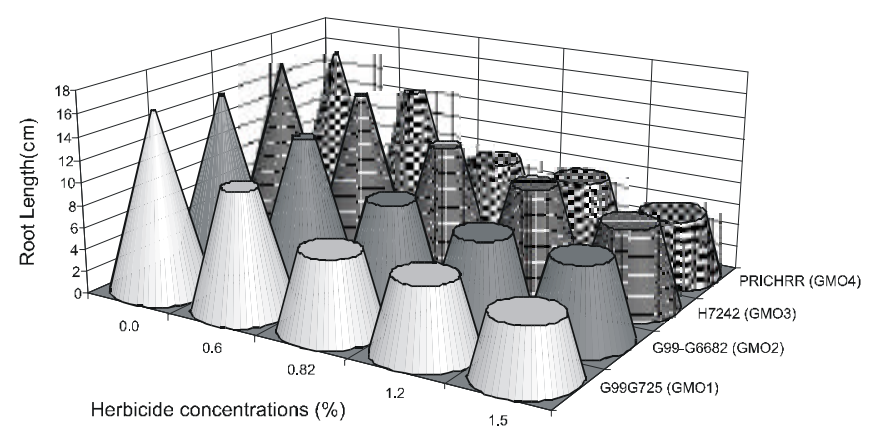

Figure 3 - Seedling root length of GMO soybean cultivars, after pre imbibing the seed for $16 \mathrm{~h}$ in a substrate varying herbicide concentrations.

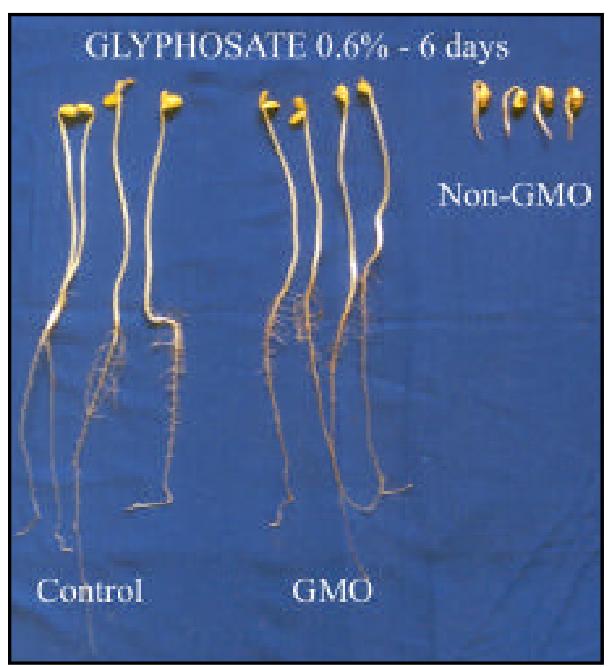

Figure 4 - Six day old GMO and non-GMO soybean seedlings after pre-imbibing the seed for $16 \mathrm{~h}$ in a substrate containing $0.6 \%$ herbicide solution.

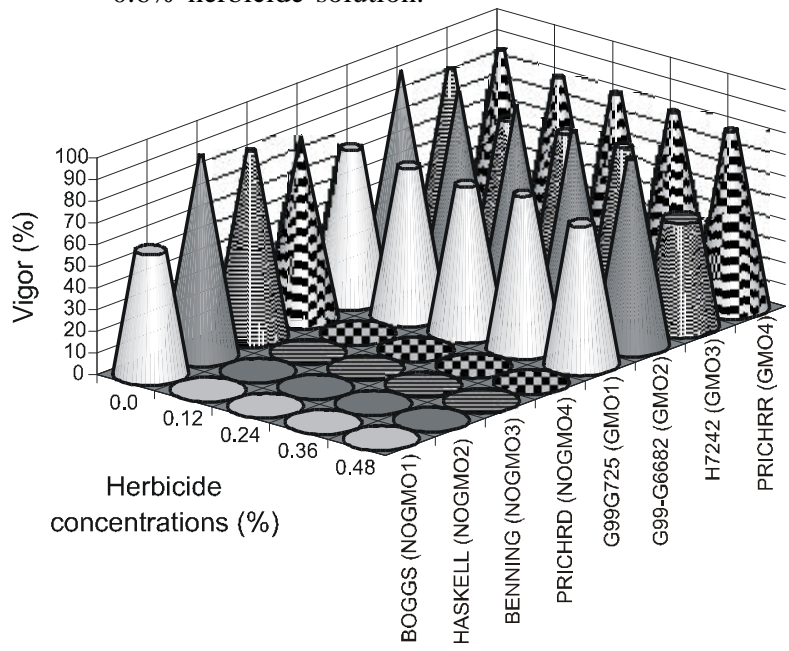

Figure 5 - Vigor of soybean cultivars, after imbibing the seeds in solutions of varying concentrations of glyphosate herbicide for 1 hour $/ 30^{\circ} \mathrm{C}$ before germinating for three days.

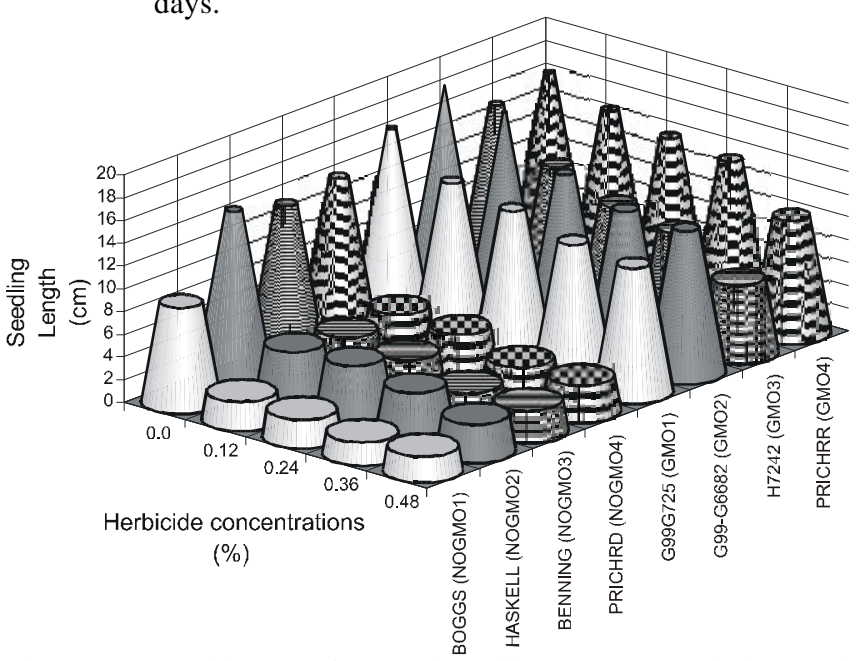

Figure 6 - Total length of normal seedlings (GMO) and abnormal (non-GMO), after imbibing the seeds in varying concentration of herbicide solution for 1 hour $/ 30^{\circ} \mathrm{C}$ before germinating for three days. 
cific enzyme in the metabolism of aromatic amino acids, 5-enolpyruvylshikimate-3-phosphate synthetase (EPSPS), resulting in plant death (Padgette et al., 1995). In the presence of glyphosate, non-GMO seedlings germinate normally, but subsequent growth is slowed increasingly until complete stop. The plant then decays (Brecke \& Duke, 1980).

The herbicide concentration necessary to stop the germination of the non-GMO cultivars, in study 1 , when the seeds were pre-imbibed in the substrate with the herbicide solution, was $0.6 \%$, whereas when the seeds were placed directly in herbicide solution, study 2 , only $0.12 \%$ was needed. In this second protocol, seeds were imbibed for one hour at $30^{\circ} \mathrm{C}$. This period corresponds to the phase I of the imbibition process, characterized by a fast water absorption, controlled by quantity of water and temperature (Bewley \& Black, 1994).

The GMO cultivars were resistant to all herbicide concentrations although there was a reduction in the vigor (Figure 5), in the total length of normal seedlings (Figure 6 ), in the hypocotyl length (Figure 7) and in the root length (Figure 8), as the herbicide dose was increased. Seed im-

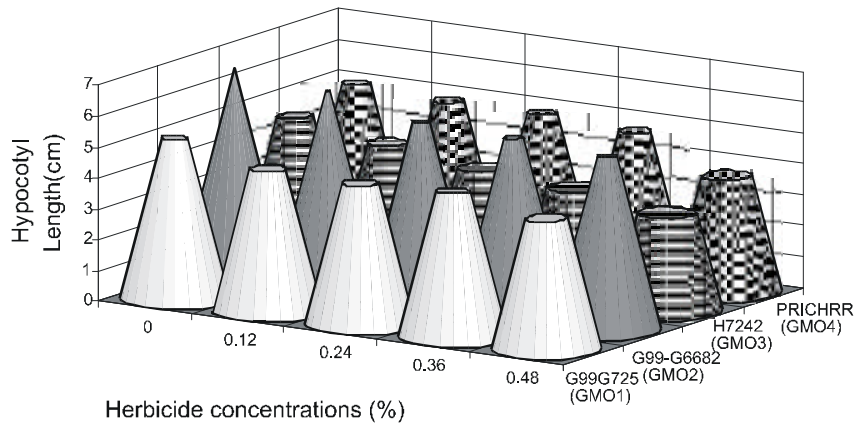

Figure 7 - Hypocotyls length of seedlings of GMO soybean cultivars, after imbibing the seeds in varying concentrations of herbicide solutions for 1 hour $30^{\circ} \mathrm{C}$ before germinating for three days

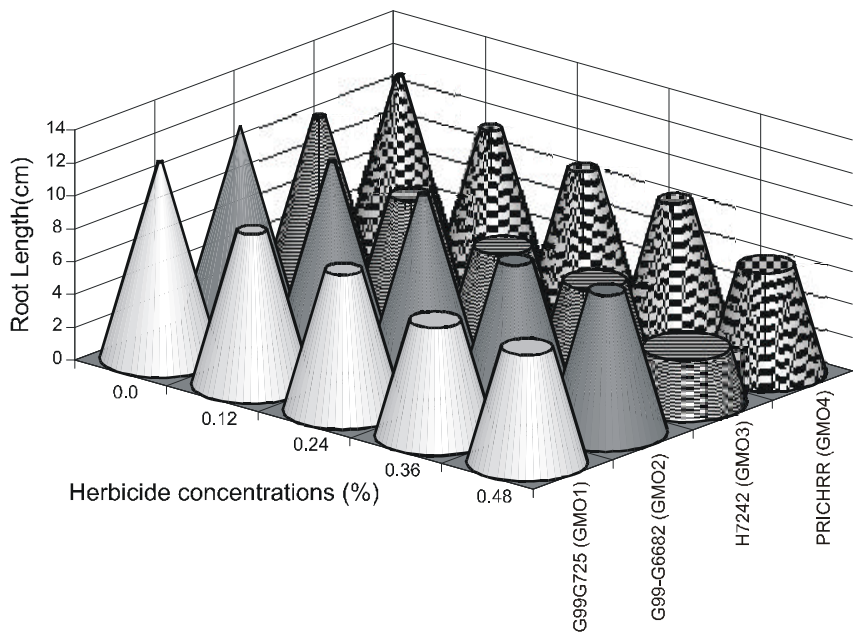

Figure 8 - Root length of seedlings of GMO soybean cultivars, after imbibing the seeds in varying concentrations of herbicide solutions for 1 hour $/ 30^{\circ} \mathrm{C}$ before germinating for three days. bibition for one hour in all solutions of glyphosate caused a reduction in the evaluated parameters of GMO cultivars in relation to the control. Similar results were obtained with transgenic rice seeds after being imbibed for six hours in ammonium gluphosinate solutions (Lilge, 2001).

In this study the herbicide affected the roots more drastically than the hypocotyls. According to Parakh (1955), reduction in root length was an excellent criterion for evaluating the effects of the herbicides. Damage caused by herbicide in germination, root length and total length of normal GMO seedlings, compared with the control, was greater than in study 1 . It is important to note that in study 2, seeds were also submitted to temperature stress when imbibed in the herbicide solution.

Among the GMO cultivars, H7242 had less seed vigor during the $30^{\circ} \mathrm{C}$ imbibing test. Germination was reduced from 95\% to 76\%. In Figures 5, 6, 7, and 8, this cultivar had less resistance to the herbicide in all concentrations because of less seed vigor. This loss of resistance was not observed in study 1 , where seeds were not submitted to stress during exposure to the herbicide. On the other hand, the cultivar G99G6682, with high seed vigor, exhibited less reduction in the germination percentage (99\% to 92\%) when immersed in the herbicide solution for one hour at $30^{\circ} \mathrm{C}$, and had less damage in the roots in all herbicide concentrations.

Distinction between GMO and non-GMO seedlings can be set with the methodology, in study 2, after three days, independently of the seed vigor of the cultivar. The non-GMO seedlings started their germination process but were inhibited by the herbicide, producing abnormal seedlings with drastic reductions on the total seedling length, root growth and secondary root inhibition. Although all concentrations permitted the GMO and non-GMO distinction, the lowest herbicide concentration $(0.12 \%)$ elicited better differentiation between the evalu-

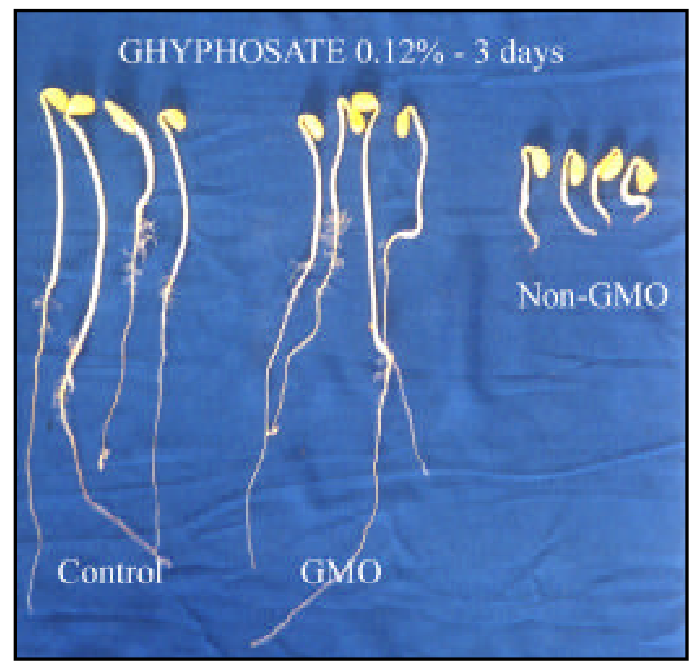

Figure 9 - Three day old GMO and non-GMO soybean seedlings, after imbibing the seeds in $0.12 \%$ herbicide solution. 
ated parameters because it caused less damage to the GMO seedlings, making identification of geneticallymodified cultivars easy on the third day of the germination test (Figure 9).

After five days, in the $0.0 \%$ herbicide concentration, the less vigorous seedlings had opportunity to grow and produce normal seedlings that were not counted in the third day. The non-GMO cultivars maintained their germination inhibition as in the third day, and abnormal seedlings had the same symptoms.

Although abnormal seedling of non-GMO developed slightly more as compared to the third day, they were easily distinguished from the GMO seedlings in all concentrations. The lowest concentration $(0.12 \%)$ caused less damage to the GMO cultivars, in all evaluated parameters and is therefore the preferred concentration.

Both methods (study 1 and 2) are effective in identifying transgenic soybean seeds resistant to herbicides that have glyphosate as active ingredient. The methodology gave clear distinctions in every cultivar independent of the initial physiological quality of the seeds.

When using paper pre-imbibed with herbicide (study 1), the $0.6 \%$ concentration was the most appropriate to identify seeds that contain the resistant gene. Whereas, imbibing the seeds in herbicide solutions (study 2 ) showed that the $0.12 \%$ concentration of active ingredient made it possible to efficiently identify the GMO seeds.

Comparing both methods, there was less damage in germination, root length and total length of the seedlings of GMO genotypes, in all concentrations used if preimbibing the substrate in herbicide (study 1 ). The advantage of the study 2 , where the seed was imbibed in herbicide solutions, is faster results, allowing the identification of the transgenic cultivars in three days, which is an important issue for commercialization. Moreover, it involves less labor, less material and it avoids direct contact between the herbicide and the analyst that occurs when the seed are placed in the paper imbibed with herbicide. The developed methodologies are fast, inexpensive and require neither sophisticated equipment nor trained technician, making it possible to standardize and readily adopt in seed laboratories.

\section{CONCLUSIONS}

The methods of pre-imbibing the substrate with herbicide solution and imbibing the seeds in herbicide solution are efficient and effective methods to identify soybean seed resistant to the herbicide glyphosate. It is possible to identify the genetically-modified soybean seeds after three days, by imbibing the seed in $0.12 \%$ herbicide solution and after six days if the substrate is preimbibed in a $0.6 \%$ herbicide solution. The methodologies were efficient with all cultivars, independent of their initial seed physiological quality.

\section{ACKNOWLEDGMENTS}

To CAPES (Coordenação de Aperfeiçoamento de Pessoal de Nível Superior) for the fellowship received during the period this work was carried out.

\section{REFERENCES}

ASSOCIATION OF OFFICIAL SEED ANALYSIS. Rules for testing seeds. Journal of Seed Technology, v.16, p.1-113, 1995.

BEWLEY, J.D.; BLACK, M. Seeds: physiology of development and germination. 2.ed. New York: Plenum Press, 1994. 445p.

BRECKE, B.J.; DUKE, W.B. Effect of glyphosate on intact bean plants (Phaseolus vulgaris L) and isolated cells. Plant Physiology, v.66, p.656659,1980

COBB, A. Herbicides and plant physiology. London: Chapman and Hall, 1992. 176p.

DELLA-CIOPPA, G.; BAUNER, S.C.; KLEIN, B.K.; SHAH, D.M.; FRALEY, R.T.; KISHORE, G. Translocation of the precursor of 5enolpyruvyl-shikimate-3-phosphate synthase into chloroplasts of higher plants in vitro. Proceedings of the National Academy of Sciences of the USA, v.83, p.6873-6877, 1986.

DODE, L.B.; OLIVEIRA, L.A.A.; GONCALVES, F.S.M.; MAGALHAES, A.M.; PETERS, J.A. Efeito do glufosinato de amonio no desenvolvimento de calos e na germinação in vitro de arroz (Oryza sativa L.) Agropecuária Clima Temperado, v.2, p.199-205,1999.

GOGGI, A.S.; STAHR, M.G. Roundup pre-emergence treatment to determine the presence of the Roundup Ready gene in soybean seed: a laboratory test. Seed Technology, v.19, p.99-102, 1997.

HASLAM, E. Shikimic acid: metabolism and metabolites. Chichester: John Wiley \& Sons, 1993.

JAMES, C. Global status of commercialized transgenic crops: 2000. Ithaca: ISAAA, 2000. (Briefs 21: Preview).

JAMES, C. Global status of commercialized transgenic crops: 2002. Ithaca: ISAAA, 2002. (Briefs 27: Preview).

LAWTON, K. Roundup of a market. Farm Industry News, p.4-8, Feb. 1999.

LILGE, C. Identificação de sementes de arroz transformado geneticamente resistente ao herbicida glufosinato de amonio. Pelotas: UFPel/Faculdade de Agronomia Eliseu Maciel, 2001. 21p. (Dissertação - Mestrado).

MAGALHAES, A.M.; FRANCO, D.F.; ANDRES, A.; ANTUNES, P.; LUZZARDI, R.; DODE, L.B.; TILLMANN, M.A.A.; SILVA, M.P. Método para identificação de arroz transgênico resistente ao herbicida glufosinato de amônio. Agropecuária Clima Temperado, v.3, p.31-38, 2000.

NASCIMENTO, W.M.; TORRES, A.C.; PAIVA, S.A.V.; TAYLOR, M.; CANTLIFFE, D.J. Bio-assay for detection of glyphosate tolerance in lettuce transgenic seeds. In: INTERNATIONAL SEED TESTING CONGRESS, 26., Angers, 2001. Abstracts. Zurich: ISTA, 2001. p.18-20.

OLSON, J. GMO-free zone? Farm Industry News, p.68-73, Feb. 2000.

PADGETTE, S.R.; KOLACZ, K.H.; DELANNAY, X.; RE, D.B.; LAVALLEE, D.J.; TINIUS, C.N.; RHODES, W.K.; OTERO, I.; BARRY, G.F.; EICHHOLTZ, D.A.; PESCHKE, V.M.; NIDA, D.L.; TAYLOR, N.B.; KISHORE, G.M. Development, identification, and characterization of a glyphosate-tolerant soybean line. Crop Science,v.35, p.1451-1461, 1995.

PARAKH, J.S. Herbicidal effects on germination of certain crop seeds Gainesville: University of Florida, 1955. 79p. (Thesis - M.S).

SEED WORLD. The pressure to certify non-GMOs terminating the terminator gene the biotech approach to seed health competing with the multi-nationals. Seed World, v.137, p.18-21, 1999.

SEED WORLD. GM Soybean approved status. Seed World, v.139, p.13, 2001.

STEINRUCKEN, H.C.; AMRHEIN, N. The herbicide glyphosate is a potent inhibitor of 5-enolpyruvyl shikimic acid-3-phosphate synthase. Biochemical and Biophysical Research Communications, v.94, p.1207-1212, 1980.

$\overline{\text { Received April 04, }} 2003$

Accepted February 05, 2004 